\title{
AQUEOUS LEAF EXTRACT OF ROTHMANNIA LONGIFLORA IMPROVES BASAL METABOLIC RATE AND ELECTROLYTE PARAMETERS IN ALLOXAN INDUCED DIABETIC RATS
}

\author{
D. E. IKPI, A. O. OBEMBE AND C. O. NKU \\ Department of Physiology, College of Medical Sciences, University of Calabar, Calabar, Nigeria. E-mail: \\ ikpidanielewa@yahoo.com.
}

Summary: This study evaluated the action of aqueous leaf extract of Rothmannia longiflora on basal metabolic rate and electrolyte profile of alloxan-induced diabetic rats. Fifteen male Wistar $(135-140 \mathrm{~g})$ were assigned to 3 groups of 5 rats each. Group 1 which served as control received placebo treatment; Group 2 - the diabetic (untreated) group also received placebo treatment whereas Group 3 - the extract treated diabetic group was administered the extract $(15 \mathrm{~g} / \mathrm{kg}$ body weight) by oral administration for 14 days. Results of BMR measurement showed a significant increase $(\mathrm{P}<0.01)$ in BMR level of Diabetic untreated group $(1.03 \pm 0.02 \mathrm{ml} / \mathrm{hr} / \mathrm{g})$ when compared to the Control group $(0.79 \pm 0.07 \mathrm{ml} / \mathrm{hr} / \mathrm{g})$. Extract treatment significantly decreased $(\mathrm{P}<0.05) \mathrm{BMR}$ in the diabetic rats. Results of analyses of serum electrolytes and glucose showed significant decreases $(\mathrm{P}<0.01)$ in sodium and chloride concentrations in the diabetic untreated group when compared to the control. However, sodium and chloride concentrations in the extract treated diabetic were not significantly different from those of their control values. There was no significant difference in potassium and urea concentrations in the extract-treated diabetic rats with respect to their control values. Extract treatment significantly reduced $(\mathrm{P}<0.05)$ serum glucose level of the extract treated group when compared to the diabetic untreated group. This suggests that oral administration of Rothmannia longiflora might be beneficial for the restoration of basal metabolic rate and the improvement of electrolyte profile in diabetes mellitus.

Key words: Rothmannia longiflora, diabetes mellitus, basal metabolic rate, electrolytes

\section{Introduction}

Diabetes mellitus is not a single disease but a heterogeneous group of disorders in glucose intolerance (Sallans, 1989). Diabetes mellitus affects anabolic, catabolic and mineral metabolism (Thruston et al, 1995). These metabolic changes and diabetic complications are initiated by the generation of free radicals. World Health Organization reports that over 4.8miilion annual deaths (9\% of global total) are attributable to either diabetes or its complications.

Despite these worrisome statistics, chemotherapy management measures aimed at achieving an effective blood glucose control or utilization, in order to delay or avert the onset of complications have been faced with drawbacks and limitations. Hence, the emergence of a more promising approach of the use of natural products and synthetic agents, singly or in combination, to prevent diabetes in humans. WHO (1989) in its general assembly authenticated this approach (Bailey, 1989).

Basal metabolic rate reflects energy expenditure at rest and it is the metabolic rate determined at rest 12 to 14 hours after the last meal (Guyton and Hall, 2006). Studies have shown that there is a reduced maximal oxygen consumption in diabetes mellitus compared with non-diabetic persons (Regensteiner et al, 1995). On the other hand, some other studies have reported that basal metabolic rate is increased in diabetic condition (Fransilla-kallunki and Groop, 1992; Avesani et al. 2001).
It is however a known fact that kidney function is compromised in uncontrolled diabetes mellitus. Glycosuria, which is a pertinent diagnostic feature of diabetes causes dehydration via glucose osmotic diuresis. This dehydration is accompanied with severe loss of electrolytes including sodium, potassium, calcium, chloride and phosphates (Gaw et al, 1995; Eteng et al, 2008).

Rothmannia longiflora, is a shrub belonging to the plant family of Rubiaceae, having trumpet-like flower with fruits that are longitudinal in shape (Mauseth, 1991). It has been reported to have antimalarial effect (Asomaning, 1999) and also used in the treatment of measles and to give tribal marks. It is used as chewing stick in the treatment of filiaris, dysentery, fever and also as an analgesic and emetic (Lewis, 1977). Rothmannia longflora has been claimed to be used by traditional medicine/herbal practitioners in treating diabetes in Cross River State.

In this study, the possible change in basal metabolic rate and electrolyte parameters associated with the use of $R$. longiflora in the management of diabetes were investigated.

\section{Materials and Methods \\ Preparation of extract}

Fresh and uninfected leaves of Rothmannia longiflora were collected from the botanical garden of the University of Calabar, Calabar. The Botanical identification of the plant leaf was done 
at the Department of Botany, University of Calabar, Calabar, Nigeria where voucher samples are kept for reference. The leaves collected were rinsed with distilled water and dried under shade. The dry leaves were ground into coarse powder after which $1160 \mathrm{~g}$ of the coarse powder was suspended in 5.8 litres of distilled water and allowed for 15 hours at room temperature. This was then filtered with a chess material and whatman No. 1 filter paper. The filtrate was then evaporated by hot air oven (Amstel Hearson oven, England) treatment at $40-50^{\circ} \mathrm{C}$. This was reconstituted in distilled water to an appropriate concentration before administration.

\section{Animals and Induction of Diabetes}

Fifteen male rats of Wistar strain weighing between $135-140 \mathrm{~g}$ obtained from the animals facility of the Department of Physiology, University of Calabar, Calabar, Nigeria were used for the study. They were allowed one week of acclimatization, after which animals were reweighted and housed in plastic cages with plastic bottom and wire mesh top (North Kent Co. Ltd.). They were under controlled environmental conditions of temperature $\left(28 \pm 2^{\circ} \mathrm{C}\right)$ and relative humidity $(50 \pm 5 \%)$ and 12 hour - light/dark cycle. The animal house facility was well-ventilated. The animals were allowed access to rat chow and distilled water ad libitum.

The rats were divided into 3 groups of 5 rats each. Two of the groups were made diabetic by intrapertoneal injection of $120 \mathrm{mg} / \mathrm{kg}$ body weight of alloxan (Sigma Chemical Co. Poole, UK) dissolved in distilled water, according to the method of Sheweita et al, 2002. This dose was administered in the morning and repeated in the evening of the same day. Control rats received only distilled water. Diabetes was confirmed by the determination of fasting blood glucose concentration on the third day post-administration of alloxan, using automatic glucose analyzer (ACCU-Chek Advantage, Roche Diagnostics $\mathrm{GmbH}$, Maannheim, Germany); showing fasting blood glucose levels of $11.0 \mathrm{mMol} / \mathrm{L}$. Group 1:Control - was given only distilled water ; Group 2: $\quad$ Diabetic control - Diabetes was induced with alloxan at a dose of $120 \mathrm{mg} / \mathrm{kg}$ body weight by intraperitoneal route; Group 3 was diabetic rats treated with Rothmannia longiflora $15 \mathrm{~g} / \mathrm{kg}$ once a day, daily. Treatment was by oral administration for 14 days.

\section{Measurement of Basal Metabolic Rate}

After 14 days of aqueous leaf extract of $R$. longiflora administration, basal metabolic rate was determined in all the groups of rats using the method described by Osim et al (1994). This method involves adding water into chamber to replace the amount of oxygen extracted from the system, thereby equilibrating the pressure within the system, using manometer to note the pressure difference. Each rat was allowed an overnight fast by withdrawing food for 12 hours prior to determination of basal metabolic rate. The measurement was done in the day between 9.00 and 13.00 hours at room temperature $\left(30^{\circ} \mathrm{C}\right)$ where the animals were housed. Each rat was placed inside a metabolic chamber containing $20 \mathrm{~g}$ of soda lime (Fischer Sci. Co. USA) to absorb carbon dioxide. The rat was allowed to settle down in the chamber for 5 minutes before closing the lid. The chamber was closed and made airtight using silicon grease. Normal breathing was allowed for 5 minutes from the time the system was airtight. Water was then added into the system to restore pressure to the original level. The volume of oxygen extracted by the rat was determined based on the amount of water added into the system. Each measurement was repeated five times at 10 minutes intervals. The average value was determined and was used to calculate the basal metabolic rate per hour. Weight of each animal was taken and recorded after the experiment. Basal metabolic rate was calculated by dividing the volume of oxygen consumed per hour by the weight of the rat (Hoar and Hickman, 1975). This is due to the fact that there is no known formula for calculating body surface area of rats, for now.

\section{Preparation of blood serum}

Twenty four hours after administration of the last dose of $R$. longiflora extract and placebo to test group and controls respectively, the animals were sacrificed by inhalation of an overdose of chloroform. Blood samples were collected by cardiac puncture into sterilized sample test tubes, after which serum was prepared by centrifugation (300g for 10 minutes) and used for serum electrolyte analysis.

\section{Assay of serum electrolytes}

Potassium ion $\left(\mathrm{K}^{+}\right)$was determined by photometric turbidemetric test of Tietz (1976) using TECO analytical kits. Sodium ion $\left(\mathrm{Na}^{+}\right)$ concentration was estimated using $\mathrm{Mg}$ uranylacetate method of HUMAN diagnostic kits according to Trinder (1951). Chloride ion (Cl-) was determined using the Mercuric thiocynate method of Tietz (1976) using Dialab Diagnostic Kits. Serum urea was estimated by Endpoint Colourimetric method of Searcy et al (1967) using Dialab kits.

\section{Statistical Analysis}

The results are expressed as mean \pm SEM. One way Analysis of Variance (ANOVA) followed by the Least Square Deviation procedure for significant F-value. Values of $\mathrm{P}<0.05$ were regarded as significant. 
Rothmannia longiflora, BMR and serum electrolytes

Table 1: Effect of oral administration of aqueous leaf extract of R. longiflora on serum glucose level), BMR) and electrolyte parameter of alloxan induced diabetic rats.

\begin{tabular}{lllllll}
\hline Group & $\begin{array}{l}\text { Serum } \\
\text { glucose }(\mathrm{mmol} / \mathrm{L})\end{array}$ & $\begin{array}{l}\mathrm{BMR} \\
(\mathrm{ml} / \mathrm{hr} / \mathrm{g})\end{array}$ & $\begin{array}{l}\mathrm{Na}^{+} \\
(\mathrm{mmol} / \mathrm{L})\end{array}$ & $\begin{array}{l}\mathrm{Cl}^{-} \\
(\mathrm{mmol} / \mathrm{L})\end{array}$ & $\begin{array}{l}\mathrm{K}^{+} \\
(\mathrm{mmol} / \mathrm{L})\end{array}$ & $\begin{array}{l}\text { Urea } \\
(\mathrm{mmol} / \mathrm{L})\end{array}$ \\
\hline Control & $4.08 \pm$ & $0.79 \pm$ & $88.08 \pm$ & $28.80 \pm$ & $5.57 \pm$ & $43.57 \pm$ \\
& 020 & 0.07 & 7.03 & 0.50 & 0.20 & 4.98 \\
Untreated & $11.80 \pm$ & $1.03 \pm$ & $77.72 \pm$ & $26.85 \pm$ & $5.31 \pm$ & $58.44 \pm$ \\
diabetic & $0.68^{* * *}$ & $0.02^{* *}$ & $0.47 * *$ & 0.29 & 0.25 & 10.44 \\
Extract treated & $6.04 \pm$ & $0.85 \pm$ & $81.27 \pm$ & $28.46 \pm$ & $4.50 \pm$ & $54.22 \pm$ \\
diabetic & $0.42^{*}$ & 0.06 & 7.85 & 0.96 & 0.34 & 7.25 \\
\hline
\end{tabular}

$\mathrm{P}<0.05$ compared with diabetic control; $* * \mathrm{P}<0.01$ compared with control; $* * * \mathrm{P}<0.001$ compared with control

\section{Results}

Effect of $R$. longiflora leaf extract on basal metabolic rate

The results of measurement of basal metabolic rate showed that there was a significant increase $(\mathrm{P}<0.01)$ in BMR level in the Diabetic untreated group $(1.03 \pm 0.02 \mathrm{ml} / \mathrm{hr} / \mathrm{g})$ compared to the control group $(0.79 \pm 0.07 \mathrm{ml} / \mathrm{hr} / \mathrm{g})$. Extract treatment significantly decreased $(\mathrm{P}<0.05)$ basal metabolic rate in the extract treated diabetic rats group when compared with that in the diabetic untreated group (table 1).

\section{Effect of extract on serum electrolyte}

The results of electrolyte profile are shown in table 1 . There was a significant decrease $(\mathrm{P}<0.01)$ in sodium ion $\left(\mathrm{Na}^{+}\right)$concentration in the diabetic untreated group $(77.72 \pm 0.47 \mathrm{mmol} / \mathrm{L})$ when compared to the control $(88.06 \pm 7.03 \mathrm{mmol} / \mathrm{L})$. However, the result for the extract treated diabetic group $(81.27 \pm 7.85 \mathrm{mmol} / \mathrm{L})$ was not significantly lower when compared to the control.

Similarly, there was a significant decrease $(\mathrm{P}<0.01)$ in chloride ion $(\mathrm{Cl}-)$ in the Diabetic untreated group $(26.85 \pm 0.29 \mathrm{mmol} / \mathrm{L})$ when compared to the control $(28.80 \pm 0.50 \mathrm{mmol} / \mathrm{L})$. The result for the extract treated diabetic group $(28.46 \pm 0.96 \mathrm{mmol} / \mathrm{L})$ was similar to that of the control group.

As shown in the table below, there were no significant differences $(\mathrm{P}>0.05)$ in potassium ion $\left(\mathrm{K}^{+}\right)$concentration in the diabetic untreated group $(5.31 \pm 0.25 \mathrm{mmol} / \mathrm{L})$ and extract treated diabetic group $(4.50 \pm 0.34 \mathrm{mmol} / \mathrm{L})$ when compared to the control $(5.57 \pm 0.20 \mathrm{mmol} / \mathrm{L})$ group.

There was a non-significant increase in serum urea in the diabetic untreated group $(58.44 \pm 10.14 \mathrm{mmol} / \mathrm{L})$ when compared to the control group $(43.57 \pm 4.98 \mathrm{mmol} / \mathrm{L})$. There was also no significant difference in urea concentration in the extract treated diabetic group $(54.22 \pm 7.25$ $\mathrm{mmol} / \mathrm{L}$ ) when compared to the control.

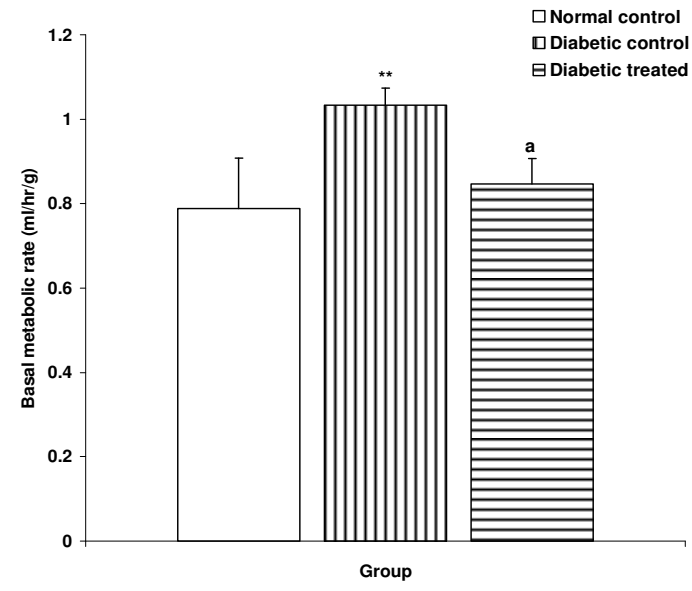

Fig. 1 Histogram showing basal metabolic rate in the different experimental groups. Values are given as mean $+\mathrm{SEM}, \mathrm{n}=5$. ${ }^{*} \mathrm{P}<0.01$ vs $\mathrm{NC}, \mathrm{a}=\mathrm{P}<0.05$ vs $\mathrm{DC}$.

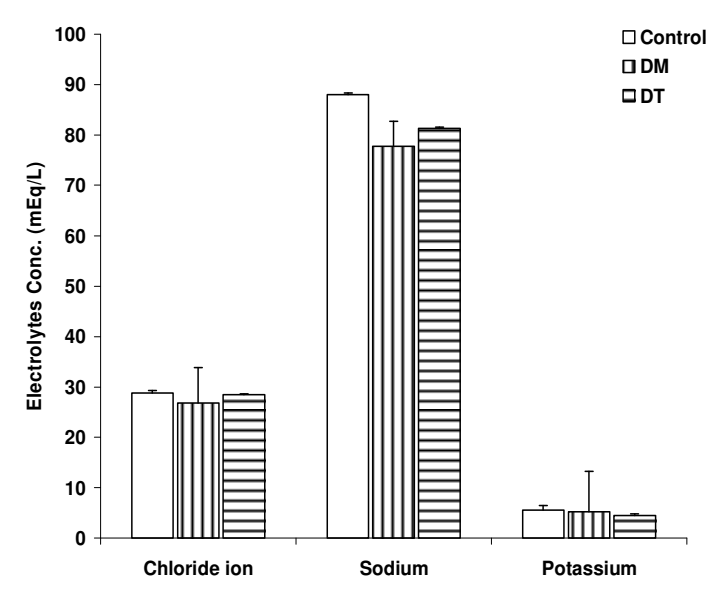

Fig. 2 Comparison of chloride, sodium and potassium in the different experimental groups. Values are mean $+S E M, n=6$. 


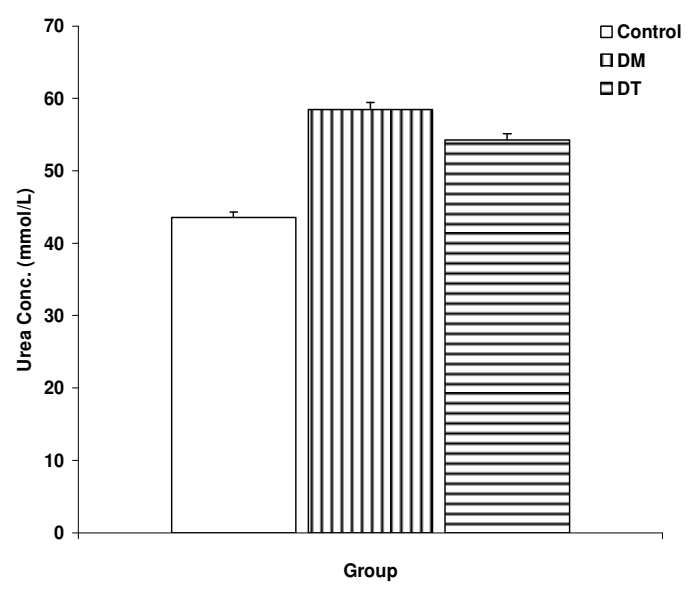

Fig. 3 Comparison of urea levels in the different experimenta groups. Values are mean \pm SEM, $n=6$.

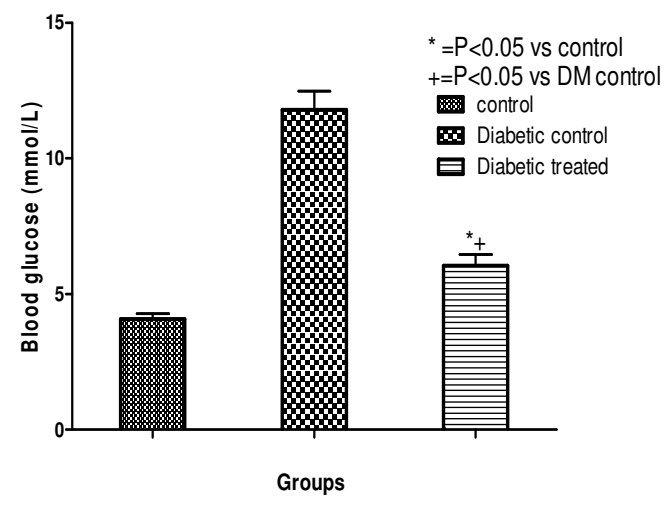

Fig. 4: Effect of R. longiflora leaf extract on blood glucose level

\section{Discussion}

Diabetes mellitus is a disease that affects anabolic, catabolic and mineral metabolism (Thruston et al, 1995). In this present investigation, there was a significant increase $(\mathrm{P}<0.01)$ in $\mathrm{BMR}$ in the Diabetic group when compared to the control group. This collaborates earlier reports by Avesani et al (2001) and Nawata et al (2004) that basal metabolic rates which represents energy expenditure at rest is elevated in Diabetes mellitus. The rise in BMR is attributed to increased breakdown of lipids and proteins, as lipids have a higher concentration of energy than do carbohydrates. Therefore in their breakdown, BMR is raised (Owu et al, 2006). The present study shows that oral administration of aqueous leaf extract of $R$. longiflora reduced BMR in diabetes mellitus. It is plausible to suppose that the bioactive constituents of the extract may have caused a recline in lipid degradation and oxidation, thus causing the decrease in BMR.
As shown in Table 1, serum sodium level was observed to decrease significantly following diabetes induction. Glucose excretion in urine by diabetics engenders an osmotic diuresis (dehydration) (Loeb, 1991), leading to loss of electrolyte with dehydration. Treatment with the extract significantly reversed the decrease in serum sodium ion level when compared to the diabetic group. It may be that as treatment gradually removes glucose from blood and urine, dehydration also disappears. This could eventually lead to water retention in the ECF to cause dilutional hyponatraemia. The mechanism follows the same pattern for the chloride ion concentration, which is known to have similar cellular transmembrane transport.

Potassium level changes in serum usually alternate with those of sodium (Loeb, 1991). Diabetic acidosis which is pronounced in most diabetic conditions usually cause decrease of potassium excretion in urine, and so impose increased retention in serum. In this investigation, the change in potassium is not significant.

Urea level in the diabetic control was nonsignificantly higher when compared to the control group. This observation is not surprising. Deficiency of insulin, an anabolic hormone, and inability of glucose to reach the extra hepatic tissues induces gluconeogenesis as an alternate route of glucose supply (Robinson and Johnson, 1997). Gluconeogenesis is sustained by increased proteolysis which releases free glucogenic amino acids circulated in plasma, which are deaminated in the liver, resulting in increased urea in blood (Atangwho et al, 2007). The extract treatment in our study non significantly reversed this condition. This is in line with an earlier observation that as glucose is cleared from serum and insulin effect probably reintroduced, proteolysis reclines via hormonal stimulation (Robinson and Jackson, 1997). This study suggests therefore, that extract of $R$. longiflora apart from reducing high blood glucose levels in blood, improves basal metabolic rate and electrolyte profile.

\section{References}

Atangwho, I. J., Ebong, P. E., Eteng, M. U., Eyong, E. U. and Obi, A. U. (2007). Effect of Vernonia amygdalina Del leaf on kidney function of diabetic rats. Int. J. Pharmacol. 3(2): $143-148$.

Eteng, M. U, Ibekwe, H. A, Essien, A. D. and Onyeama, H. P. (2008). Effects of Catharanthus roseus on Electrolyte Derangement induced by Chlopropamide

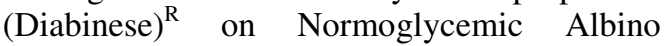
Wistar Rat. Bio-Res. 6(2): 364 - 366.

Gaw, A, R., A. Cowman; D. S. O. Reilly and J. Shepherd (1995). Clinical Biochemistry. New York. Churchill, Livingstone. 
Guyton, A. C. and Hall, J. E. (2006). Textbook of Medical Physiology $11^{\text {th }}$ edition (Philadelphia: Elsevier Saunder) pp. $884-888$.

Hoar, W. S. and Hickman Jr., G. P. (1975). A Laboratory Comparison for General and Comparative Physiology. $2^{\text {nd }}$ edition (PrenticeHall).

Loeb, S. (1991). Clinical Laboratory Test: Values and Implications. Copy right, Springhouse Corporation, Springhouse, Pennsylvania.

Nawata, K., Sohmiya, M., Kawaguchi, M., Nishiki, M. and Kato, Y. (2004). Increased resting metabolic rate in patients with Type 2 diabetes mellitus accompanied by advanced diabetic nephropathy; Metabolism 53: 1395 - 1398.

Osim, E. E., Owu, D. U., Isong, E. U. and Umoh, I. B. (1994). Influence of chronic consumption of thermoxidized and fresh palm oil diets on basal metabolic rate, body weight and morphology of tissue in rats. Discovery and Innovation 6: 389 - 396.

Owu, D. U., Antai, A. B., Udofia, K. H., Obembe, A. O., Obasi, K. O. and Eteng, M. U. (2006). Vitamin $\mathrm{C}$ improves basal metabolic rate and lipid profile in alloxan-induced diabetes mellitus in rats. J. Biosci. 31(5): $575-579$.
Robinson, G. and Jackson, D. E. (1997). Metabolic Disorder. Diabetes. In: Mechanisms of Disease. An Introduction to Clinical Science. $1^{\text {st }}$ Ed. Cambridge, Cambridge, University Press.

Sallans, L. B. (1989). The variability of diabetes mellitus. In: Diabetes Mellitus. Academic Press, London. Pp. 1 - 13.

Searcy, R. L., Reardon, J. E. and Foreman, J. A. (1967). Am. J. Med. Technol. 33: 15 - 20.

Sheweita, S. A., Newairy, A. A., Mansour, H. A. and Yousef, M. I. (2002). Effect of some hypoglycemic herbs on the activity of phase I and II drug-metabolizing enzymes in alloxaninduced diabetic rat. Toxicology 174: 131 139.

Thruston, J. H., McDougal, D. B. Jr., Schulz, H. R. E. (1995). Effect of acute, subacute and chronic diabetes on carbohydrate and energy metabolism in rat sciatic nerve: Relation to mechanism of peripheral neuropathy. Diabetes 44(2): 190 - 195.

Tietz, N. W. (1976). Fundamentals of Clinical Chemistry. W. B. Saunders Company, Philadelphia, PA, pp. 874.

Trinder, P. (1951). Analyst 76: 596. 